\title{
Study Overall Status Anticipated Indicator
}

National Cancer Institute

\section{Source}

National Cancer Institute. Study Overall Status Anticipated Indicator. NCI Thesaurus.

Code C94096.

Specifies whether the overall status of the study is an estimate. 